THE FLETCHER JONES FOUNDATION HUMANITIES IMPRINT

The Fletcher Jones Foundation has endowed this imprint to foster innovative and enduring scholarship in the humanities. 
The publisher and the University of California Press Foundation gratefully acknowledge the generous support of the Fletcher Jones Foundation Imprint in Humanities. 
Black Handsworth 


\section{BERKELEY SERIES IN BRITISH STUDIES \\ Edited by James Vernon}

1. The Peculiarities of Liberal Modernity in Imperial Britain, edited by Simon Gunn and James Vernon

2. Dilemmas of Decline: British Intellectuals and World Politics, 1945-1975, by Ian Hall

3. The Savage Visit: New World People and Popular Imperial Culture in Britain, 1710-1795, by Kate Fullagar

4. The Afterlife of Empire, by Jordanna Bailkin

5. Smyrna's Ashes: Humanitarianism, Genocide, and the Birth of the Middle East, by Michelle Tusan

6. Pathological Bodies: Medicine and Political Culture, by Corinna Wagner

7. A Problem of Great Importance: Population, Race, and Power in the British Empire, 1918-1973, by Karl Ittmann

8. Liberalism in Empire: An Alternative History, by Andrew Sartori

9. Distant Strangers: How Britain Became Modern, by James Vernon

10. Edmund Burke and the Conservative Logic of Empire, by Daniel I. O'Neill

11. Governing Systems: Modernity and the Making of Public Health in England, 1830-1910, by Tom Crook

12. Barbed-Wire Imperialism: Britain's Empire of Camps, 1976-1903, by Aidan Forth

13. Aging in Twentieth-Century Britain, by Charlotte Greenhalgh

14. Thinking Black: Britain, 1964-1985, by Rob Waters

15. Black Handsworth: Race in 1980s Britain, by Kieran Connell 


\title{
Black Handsworth
}

Race in 1980s Britain

\author{
Kieran Connell
}

吅

UNIVERSITY OF CALIFORNIA PRESS 
University of California Press, one of the most distinguished university presses in the United States, enriches lives around the world by advancing scholarship in the humanities, social sciences, and natural sciences. Its activities are supported by the UC Press Foundation and by philanthropic contributions from individuals and institutions. For more information, visit www.ucpress.edu.

University of California Press

Oakland, California

(C) 2019 by Kieran Connell

Library of Congress Cataloging-in-Publication Data

Names: Connell, Kieran, author.

Title: Black Handsworth : race in 1980s Britain / Kieran Connell.

Description: Oakland, California : University of California Press, [2019] | Series: Berkeley Series in British Studies ; 15 | Includes bibliographical references and index. |

Identifiers: LCCN 2018036127 (print) | LCCN 2018037563 (ebook) | ISBN 9780520971950 (ebook) | ISBN 9780520300668 (cloth : alk. paper) | ISBN 9780520300682 (paperback)

Subjects: LCSH: Blacks-England-Birmingham-Social conditions2oth century. | Handsworth (Birmingham, England)-Social conditions-2oth century. | Handsworth (Birmingham, England)Race relations-History-2oth century.

Classification: LCC DA69o.B6 (ebook) | LCC DA69o.B6 C76 2019 (print) | DDC 305.896/042496-dc23

LC record available at https://lccn.loc.gov/2018036127

Manufactured in the United States of America

$\begin{array}{llllllll}26 & 25 & 24 & 23 & 22 & 21 & 20 & 19\end{array}$

$\begin{array}{llllllllll}10 & 9 & 8 & 7 & 6 & 5 & 4 & 3 & 2 & 1\end{array}$ 
For A.S.F.

and

in memory of K. H.C. 